\title{
Indvielse af nyt museum i Gram - Et museum med bid $i$
}

Af geolog Ulla V. Hjuler, GeologiskNyt

På en rigtig "aprilsdag" i maj med skiftende regn og solskin blev det nye museum ved Gram indviet. Mange var dukket op for at være med til at fejre begivenheden og se de flotte bygninger på tættere hold.

Søndag d. 8 maj fik sønderjyderne et flot, nyt museum, som de kan være stolte over! Det er en fornøjelse at se de spændende, fossiler, og bygningerne forøger oplevelsen.

\section{Behørig fejring på åbningsdagen}

Den festlige åbning begyndte med en række festtaler af bl.a. Grams borgmester Hans Peter Gejl, der indledte med en historisk baggrund for den oprindelige bygning på stedet, der tidligere var garage. Heri opbevaredes en kompaktor (tung maskine, der kan knuse og komprimere affald på lossepladser) - der lå nemlig engang en losseplads hér. Det havde man næppe gættet. Borgmesteren takkede til slut alle, der har bidraget og overrakte et gammelt maleri til museets leder Flemming Roth.

Også Amtsborgmester Carl Holst udtrykte sin glæde ved det nye museum og brugte som gennemgående tråd naturen i sin tale. Bl.a. citerede han fra den afdøde, lokale forfatter Carl Ewald, der var inspireret af naturen: "Når vi arbejder med naturen, forstærker vi vores egen fantasi". Amtsborgmesteren uddelte også sproglige roser til museets arkitektur og placering i naturen og slog fast, at museet står centralt som medspiller i formidling af naturvidenskaben - bl.a. i kraft af det aktive element - at publikum selv kan komme ud og grave i lergraven.

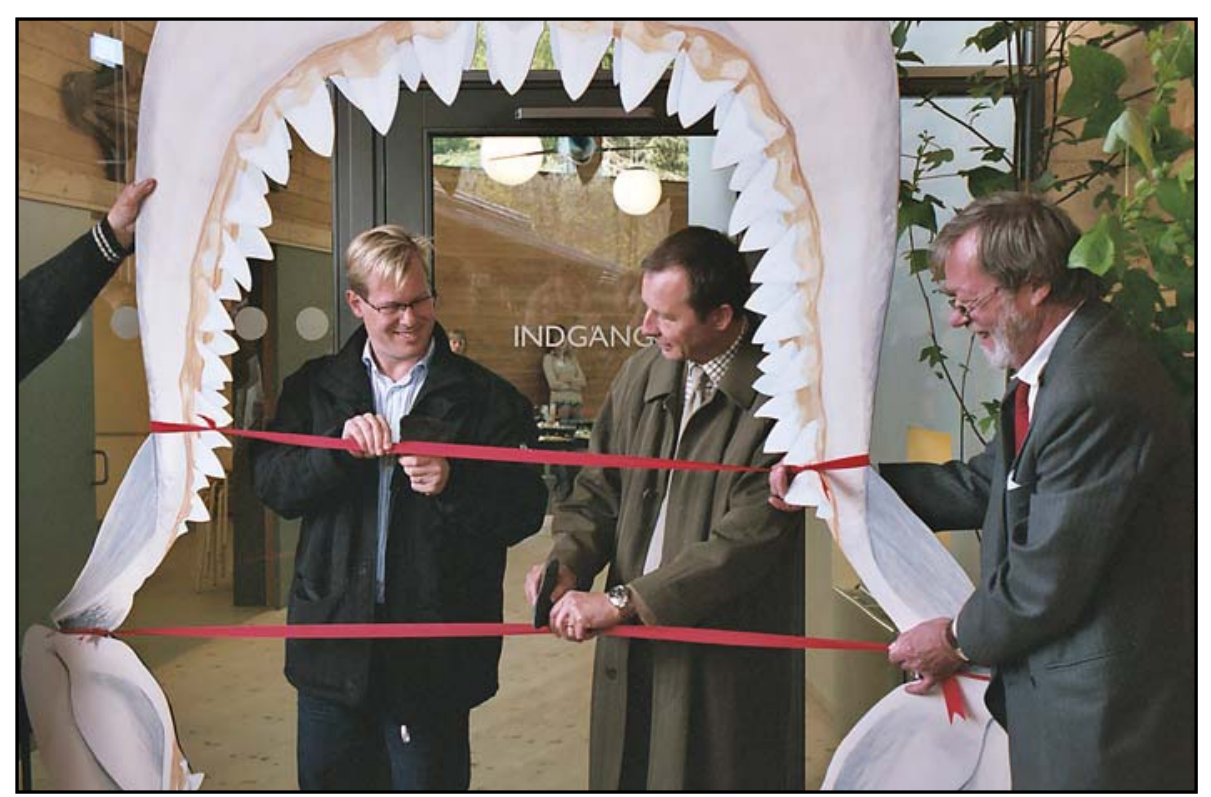

Det røde bånd klippes med hajtandsafstøbningerne. (Foto: Ulla V. Hjuler)

Museumsleder Flemming Roth rundede selv den lange række af taler af. Han omtalte det nye museum som et vidensmuseum: "Man kan lære ved at se, røre og opleve!" Det giver lidt "skolepræg", og museumslederen slog da også fast, at viden ikke kommer uden skoling! Efter at have draget paralleller mellem evolutionen og museets historie sluttede Flemming Roth af med at udtrykke en varm tak til alle, der har støttet det naturvidenskabelige og palæontologiske museum, og så blev museet åbnet på storslået vis.

Amtsborgmesteren og borgmesteren fik hver udleveret en afstøbning af en stor hajtand, hvori en kniv var monteret. Den røde snor blev således skåret over på ægte geologisk vis, og publikum fik nu adgang til museet gennem en stor afstøbning af et hajgebis.
Det kan anbefales

Imens publikum nød de nye faciliteter, kunne de indtage et glas vin og smage på de fine retter, der var stillet op flere steder i bygningerne. Museet fik foræret en del træer bl.a. en troldnød og et magnolietræ, som de havde ønsket sig til at pryde omgivelserne omkring museet.

Det kan virkelig anbefales at besøge museet. Dels kan man nyde de flotte, udstillede fossiler og plancherne - og har man lidt uro i benene, er det bare med at komme ned i lergraven og se, om der ligger et hvalskelet og venter på at blive udgravet. Så kan man altid vende tilbage til museets nyindrettede laboratorium og studere sine fund.

GeologiskNyt ønsker tillykke med det nye museum.

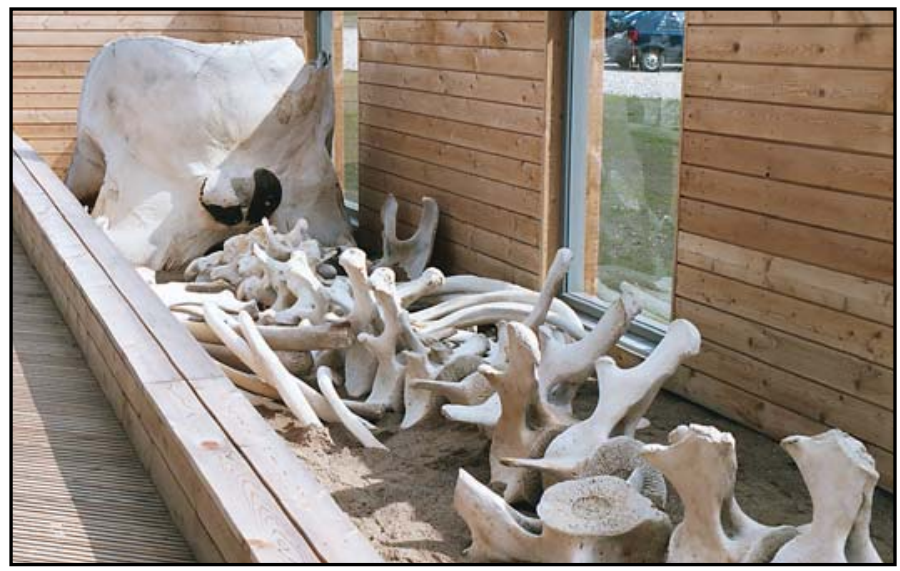

Skelet af en kaskelothval, der strandede sidste år. (Foto: Ulla V. Hjuler)

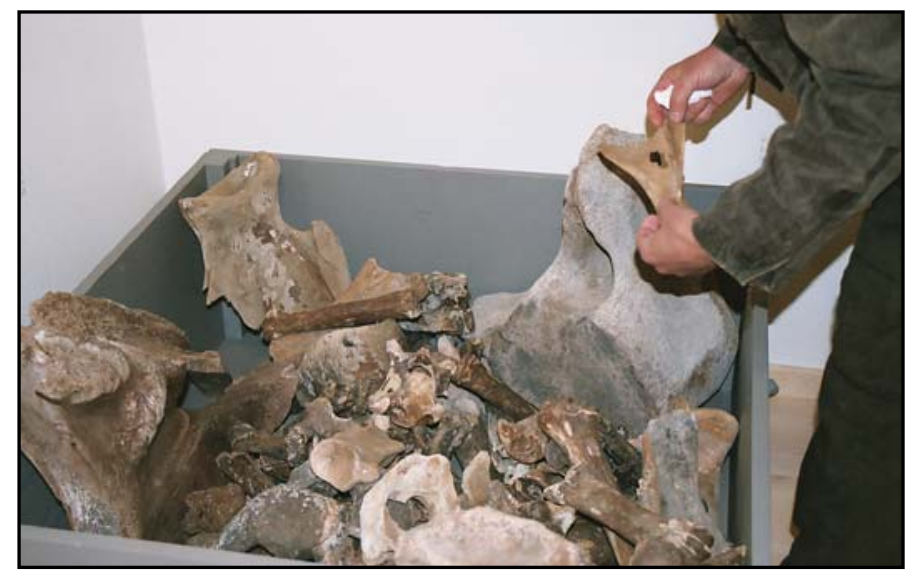

Her kan publikum komme i ncerkontakt med hvalerne. (Foto: Ulla V. Hjuler) 